\title{
Sosiaalipedagoginen katse ja ajan haasteet
}

\author{
Juha Hämäläinen
}

$\bigvee$

uoden 2020 Sosiaalipedagogiikan päivät toteutettiin poikkeuksellisella tavalla poikkeuksellisissa olosuhteissa. Muutokset alkuperäisestä suunnitelmasta verkkototeutukseen vaativat järjestäjiltä huomattavia lisäponnistuksia. Myös osallistujille järjestelyistä aiheutui haastetta. Lopulta toteutus onnistui loistavasti ja päivistä muodostui ikimuistettava, tieteellisesti korkeatasoinen tapahtuma.

Etäosallistuminen ei haalistanut päivillä kuultujen esitysten ja niiden ympärillä käytyjen keskustelujen tasoa. Otsikointi Ekologinen sivistys ja vastuu tarjosi aika ajoin suurenmoiseksi yltäneelle keskustelulle inspiroivan ja vahvasti nykypäivän yhteiskunnalliseen debattiin kiinnittyvän näkökulman.

Aiempien Sosiaalipedagogiikan päivien tavoin päivillä käyty ajatusten vaihto osoitti, että sosiaalipedagogiikka antaa hedelmällisen kehyksen erilaisten yhteiskunnallisten teemojen tarkastelulle. Keskustelu kosketteli paitsi ajankohtaisia kysymyksiä myös sosiaalipedagogiikan teoreettista itseymmärrystä, alan pyrkimystä tulkita ja määritellä itseään, jäsentää omaa luonnettaan tieteenä, oppialana ja pedagogisena käytäntönä.

Suomalaiseen sosiaalipedagogiseen keskusteluun on sisältynyt vahva pyrkimys kehittää sosiaalipedagogiikkaa tieteenä ja akateemisena oppialana, jolloin aihealuetta on hahmotettu erityisenä kasvatusfilosofisena kysymyksenasetteluna, omintakeisena keskusteluperinteenä ja tiettynä pedagogisen ajattelun ja toiminnan kehityssuuntana. Tämä läpäisee nykykeskustelun: ala näyttäytyy monipuolisena ajattelun ja toiminnan kenttänä, joka elää ajassa. 
Kullakin aikakaudella on omat kysymyksensä ja haasteensa. Tieteenä ja kasvatusfilosofisen keskustelun traditiona sosiaalipedagogiikka sekä antaa panoksensa aikalaiskeskusteluihin että tarjoaa ajattomia näkymiä ihmiseen ja yhteiskuntaan. Suomalainen sosiaalipedagogiikan tiedeluonnetta korostava ajattelutapa ja siihen liittyvä pyrkimys luoda sosiaalipedagogiselle ajattelulle ja toiminnalle vahva tieteellinen perusta houkuttelee suuntaamaan katsetta kokonaisvaltaisesti alan historiaan, nykypäivää ja tulevaisuuteen.

Yhtenä esimerkkinä nykypäivän mitä moninaisimmista yhteiskunnallisista haasteista voidaan pitää Sosiaalipedagogiikan päivien järjestelyihinkin vaikuttanutta viruspandemiaa. Kyse on maailmanlaajuisesta akuutista yhteiskunnallisesta kriisistä, joka on koetellut rajusti myös omaa yhteiskuntaamme. On paikallaan kysyä - kuten Sosiaalipedagogiikan päivien keskusteluissa kysyttiin - miltä tällainen kriisi näyttää sosiaalipedagogiikan näkökulmasta ja mitä annettavaa sosiaalipedagogiikalla on sen käsittelyyn.

Se, miten tulkitsemme sosiaalipedagogiikan kontribuutiota, ilmentää käsitystämme siitä, mikä sosiaalipedagogiikalle on tunnusomaista erityisenä ajatustapana ja -perinteenä. Voimme myös yrittää tunnistaa käsityksemme taustaa: miksi ajattelemme niin kuin ajattelemme ja mihin tulkintamme perustuu? Vastaavaa ajatuskoetta voi hyvin soveltaa mihin tahansa ajankohtaiseen aihepiiriin ja kysyä, mitä jokin ajan ilmiö on suhteessa sosiaalipedagogiikkaan - ja sosiaalipedagogiikka suhteessa siihen.

Sosiaalipedagogiikan elinvoimaisuus perustuu olennaisesti kykyyn uudistua ja pysyä kiinni ajassa. Kyse ei kuitenkaan ole siitä, että irrottaudutaan juuriltamme, pikemminkin päinvastoin. Omankin aikamme yhteiskunnallisten haasteiden valossa on hyvinkin perusteltua, että vaikka monet kysymykset ovat uusia, kysymme itsepintaisesti ja herkällä korvalla, minkälaisia vastauksia traditio meille antaa.

Herkkyys kuunnella traditiota ja ymmärtää menneiden aikakausien keskusteluja luo edellytykset käsitellä nykypäivän haasteita ja löytää uusia tuoreita ratkaisuja. Vuoden 2020 Sosiaalipedagogiikan päivät osoitti, että olemme Suomessa hyvin ymmärtäneet tämän. Rakennamme sosiaalipedagogiikan tulkintaamme osana teoriatradition jatkumoa siinä, miten kohtaamme oman aikamme pulmat ja miten visioimme tulevaisuutta.

Suomessa tiedostamme, että sosiaalipedagogiikan teoriahistoriaa ovat luoneet monet meitä oppineemmat ja viisaammat ajattelijat, mikä estää väheksymästä historiasta kumpuavaa henkistä pääomaa. Vaikka tieteellisessä keskustelussa ei lähtökohtaisesti kumarrella auktoriteetteja, olemme hyvin oivaltaneet, että voimme oppia teoriatraditiolta paljon sellaista, mikä auttaa vastaamaan nykypäivän haasteisiin. Samalla jatkuvuus on turvattu. 
Sosiaalipedagogiikan identiteetille tieteenä, oppi- ja koulutusalana ja pedagogisen työn kenttänä on ensiarvoisen tärkeää, että juuret tunnetaan ja tunnustetaan. Se ei kuitenkaan riitä. Alalle tarvitaan uusia lahjakkuuksia, tuoreita aivoja, luovia ajattelijoita, jotka kykenevät osallistumaan nykypäivän yhteiskunnalliseen ja akateemiseen keskusteluun ja rakentamaan haasteisiin sosiaalipedagogiseen kysymyksenasetteluun perustuvia vastauksia.

Vaikka yksittäisillä ajattelijoilla on merkittävä rooli jokaisen tieteenalan kehityksessä, alan kehittyminen on aina kollektiivinen prosessi. Se perustuu tutkijayhteisössä tapahtuvaan tieteelliseen keskusteluun, jossa erilaiset näkökannat punnitaan. Tieteelliset konferenssit, kuten jokavuotiset Sosiaalipedagogiikan päivät, ovat yksi tiedeyhteisön tapa käydä tätä keskustelua. Vuoden 2020 Sosiaalipedagogiikan päivien keskustelu todisti, että tästä on syytä pitää kiinni, vaikka olosuhteet vaatisivatkin erityisponnisteluja.

Maailmankuvamme on väistämättä sirpaleinen ja puutteellinen. Tarvitsemme kuitenkin kokonaisnäkemystä ihmisestä ja maailmasta rakentaaksemme asianmukaisen tulkinnan sosiaalipedagogiikasta. Tieteenalana sosiaalipedagogiikka jäsentää ihmisen maailma- ja yhteiskuntasuhdetta kasvatuksen ja sivistyksen näkökulmasta. Siinä mennään kursailematta syvälle ihmisen eksistenssin fundamentteihin, olemassaolon perusteisiin.

Käsityksemme sosiaalipedagogiikasta perustuu aina, väistämättä, johonkin antropologiaan, käsitykseen siitä, mitä ihminen on ja mitä hänen pitäisi olla. Niinpä sosiaalipedagogiikan teorianmuodostus tarjoaa itse kullekin hyvän mahdollisuuden työstää omaa ihmiskäsitystä ja maailmankuvaa, oikeastaan myös edellyttää sitä. Tulevaisuuden suunta ratkaistaan pitkälti aatteiden kilpailuna, jossa kriittisin aines koskee käsitystä ihmisestä.

On tärkeää ymmärtää, että sosiaalipedagogiikka ei pelkisty vain johonkin tiettyyn ihmiskäsitykseen ja maailmankuvaan. Tieteenä se koostuu erilaisista itseymmärryksistä. Alan oppihistoria käsittelee näitä erilaisia tutkintatapoja ja niiden katsomuksellisia taustoja. Olennaista on myös kysyä, miten sosiaalipedagogiikka suhteutuu lähitieteisiin kuten psykologiaan, sosiologiaan ja politiikkatieteisiin ja näiden piirissä kehiteltyihin teorioihin.

Vaikka sosiaalipedagoginen ajattelu ei palaudu johonkin tiettyyn ajattelutapaan, maailmankuvaan tai ihmiskäsitykseen, alan teorianmuodostus ei ole mielivaltaista. Sosiaalipedagogiselta teorialta edellytetään samojen yleispätevien logiikan ja argumentaation sääntöjen noudattamista kuin miltä tahansa inhimilliseltä ajatusrakennelmalta ja päättelyltä. Tämä vaatimus kytkee sosiaalipedagogisen ajattelun kaikkea tieteellistä toimintaa ohjaaviin pätevän inhimillisen ajattelun lakeihin. 
On ilmeistä, että vastauksia pedagogisen teorian ydinkysymyksiin - pedagogisen työn tavoitteisiin ja eettisiin periaatteisiin - ei löydy empiirisen tutkimuksen keinoin, ei vaikka kuinka tutkisi. Päämäärän ja tarkoituksen hahmottaminen edellyttää järkiperäistä päättelyä, vastausten tuottamista järkiperäisesti. Tältä osin sosiaalipedagogiikka on lähtökohtaisesti filosofista tutkimusta, ei sosiologista, psykologista tai vastaavaa havaintotiedon hankkimista maailmasta.

Oman käsite- ja teoriahistorian tuntemus kuuluu olennaisesti jokaisen tieteenalan itseymmärrykseen. Vaikka sosiaalipedagogiikka lainaakin empiiriseen tiedonmuodostukseen muiden sosiaalitieteiden käsitteistöä ja tutkimusmenetelmiä, sen oma kysymyksenasettelu profiloi sen selkeästi itsenäiseksi kasvatustutkimuksen, erityisesti kasvatusfilosofian tutkimusperinteeksi. Sosiaalipedagoginen kysymyksenasettelu edellyttää kasvatuksellisten arvo- ja päämääräkysymysten perinpohjaista prosessointia, ei vain tiedon tuottamista vallitsevasta kasvatustodellisuudesta.

Jokaisen kelvollisen sosiaalipedagogisen teorian on vastattava kysymykseen, mitä sosiaalipedagogiikka on. Ollakseen varteenotettava teorian on tehtävä selkoa siitä, mitä sosiaalipedagogiikka on erityisesti suhteessa sen käsitehistoriaan. Toisin sanoen, varteenotettavan teorianmuodostuksen on keskusteltava sosiaalipedagogiikan käsitteen ympärille rakentuneen keskusteluperinteen kanssa ja siltä osin pohjauduttava oman teoria- ja keskusteluperinteen tutkimukseen.

Sosiaalipedagogisen teoria- ja keskusteluperinteen tutkimuksessa on hyödyllistä kiinnittää huomiota siihen, millaisiin ihmis- ja yhteiskuntakäsityksiin, moraalioppeihin, tiedonkäsityksiin, arvoihin ja uskomuksiin tulkinnat perustuvat. Aatteellisten perusteiden erittely koskee myös sosiaalipedagogiikan vastausten ideointia nykypäivän ja tulevaisuuden haasteisiin. On tärkeää, että vastaukset ovat osuvia niin alan oman teoriahistorian kuin ajankohtaisten haasteiden kannalta.

Tällaiseen alan teoreettista itseymmärrystä ja ajan haasteita kytkevään itsereflektioon inspiroi ja haastoi meitä onnistuneesti myös vuoden 2020 Sosiaalipedagogiikan päivät. Koronakevään päivät onkin parempi muistaa niiden innostavasta ja rakentavasta sisällöstä kuin poikkeuksellisista järjestelyistä, mutta erityisiä olosuhteita ja niiden vaatimaa vaivannäköä ei myöskään sovi unohtaa. 